\title{
Synthetic Iron Oxides for Adsorptive Removal of Arsenic
}

\author{
Izabela Polowczyk • Piotr Cyganowski (iD) \\ Justyna Ulatowska • Wojciech Sawiński • \\ Anna Bastrzyk
}

Received: 3 April 2018 / Accepted: 1 June 2018 /Published online: 8 June 2018

(C) The Author(s) 2018

\begin{abstract}
Removal of arsenic from water reservoirs is the issue of great concern in many places around the globe. As adsorption is one of the most efficient techniques for treatment of As-containing media, thus the present study concerns application of iron oxideshydroxides (akaganeite) as adsorbents for removal of this harmful metal from aqueous solution. Two types of akaganeite were tested: synthetic one (A) and the same modified using hexadecyltrimethylammonium bromide $\left(A_{M}\right)$. Removal of As was tested in batch studies in function of $\mathrm{pH}$, adsorbent dosage, contact time, and initial arsenic concentration. The adsorption isotherms obey Langmuir mathematical model. Adsorption kinetics complies with pseudo-second-order kinetic model, and the constant rates were defined as $2.07 \times 10^{-3}$ and $0.92 \times 10^{-3} \mathrm{~g} \mathrm{mg}^{-1} \mathrm{~min}^{-1}$ for the samples $(\mathrm{A})$ and $\left(\mathrm{A}_{\mathrm{M}}\right)$, respectively. The difference was caused by significant decrease in adsorption rate in initial state of the process carried out for the sample $A_{M}$. The maximum adsorption capacity achieved for $(A)$ and $\left(A_{M}\right)$ akaganeite taken from Langmuir isotherm was 148.7 and $170.9 \mathrm{mg} \mathrm{g}^{-1}$, respectively. The results suggest that iron
\end{abstract}

I. Polowczyk · J. Ulatowska • W. Sawiński · A. Bastrzyk Division of Chemical Engineering, Wroclaw University of Science and Technology, Wybrzeże S. Wyspiańskiego 27, 50-370 Wrocław, Poland

P. Cyganowski $(\square)$

Division of Polymer and Carbonaceous Materials, Faculty of Chemistry, Wroclaw University of Science and Technology, Wybrzeże S. Wyspiańskiego 27, 50-370 Wrocław, Poland e-mail: piotr.cyganowski@pwr.edu.pl oxides-hydroxides can be used for As removal from aqueous solutions.

Keywords Akaganeite

Hexadecyltrimethylammonium bromide - Adsorption . Kinetics $\cdot$ Iron oxide $\cdot$ Pollution $\cdot$ Arsenic contamination

\section{Introduction}

Arsenic is one of the most hazardous pollutants in many regions of the world as it can be easily solubilized in groundwater (Giri and Patel 2011). The problem concerns USA, China, Chile, Bangladesh, Taiwan, Mexico, Argentina, Poland, Canada, Hungary, New Zealand, Japan, and India (Mohan and Pittman 2007). Arsenic contamination is usually linked with highly developed industry (mining and metallurgy), geothermic processes, volcanic eruptions, and biological activity (Smedley and Kinniburgh 2002). Arsenic in the water environment occurs both organic as well as inorganic forms. This mainly includes As oxyanions: arsenite $\left(\mathrm{H}_{2} \mathrm{AsO}_{3}{ }^{-}\right)$ and arsenate $\left(\mathrm{H}_{2} \mathrm{AsO}_{4}{ }^{-}\right)$(Sar1 and Tuzen 2009; Mohan et al. 2007). Arsenic (III) is the most toxic and mobile in the environment. It has been reported that the arsenic poisoning causes melanosis; edema; keratosis; dark spots on the chest; enlargement of liver, kidney, and spleen; and cancers of skin, lungs, and urinary bladder (Giri et al. 2011; Wang and Mulligan 2008; Choong et al. 2007). For this reason, the World Health Organization (WHO) has recommended the maximum concentration of arsenic in drinking water as $10 \mu \mathrm{g} \mathrm{L}^{-1}$ (Mohan 
and Pittman 2007). However, it was observed that the typical concentration of this metal in contaminated water used for human consumption is about 100 $300 \mu \mathrm{g} \mathrm{L}^{-1}$ (Zaw and Emett 2002).

Removal of arsenic(III) ions from water can be achieved by various techniques, such as coagulation (Song et al. 2006; Wickramasinghe et al. 2004) and reverse osmosis (Ning 2002). Most of these methods suffer from high operational cost and incomplete metal removal (Giri et al. 2011; Sharma and Sohn 2009). In contrast, adsorption is an effective method (Sar1 and Tuzen 2009; Mohan and Pittman 2007; Kundu and Gupta 2007; Pirilä et al. 2011) and can be considered as economically justified. Studies on adsorption of arsenic(III) were carried out on various adsorbents, including fly ashes (Polowczyk et al. 2010; Cho et al. 2005), activated carbon (Pattanayak et al. 2000), natural and synthetic clay materials (Guo et al. 2011; Liao et al. 2011), ion-exchange resins (Pakzadeh and Batista 2011; Kim and Benjamin 2004), multi-walled carbon nanotubes (V.K. Gupta and Saleh 2013; Saleh et al. 2011), and metal oxides (Pirilä et al. 2011; Deliyanni et al. 2006; Mostafa et al. 2011). However, charge of As(III) is neutral in the media of concern (utility water); thus, it is difficult to remove. For this reason, a potential method for treatment of As-containing wastes must consider $\mathrm{pH}$ of the environment to provide oxidation of As(III) to $\mathrm{As}(\mathrm{V})$ which species reveal ionic character (Yazdi and Darban).

Iron oxides have been widely used as adsorbents for removal of various contaminants from water, wastewater, and liquid hazardous wastes (Deliyanni et al. 2003; V. K. Gupta and Nayak 2012). Their use is limited due to the competition with the commercially available natural aluminum oxides (Anderson et al. 1976), biomass (Sar1 and Tuzen 2009), biogenic schwertmannite (Liao et al. 2011), soot (Pattanayak et al. 2000), and fly ashes (Cho et al. 2005; Aguilar-Carrillo et al. 2006; Polowczyk et al. 2010). Ferric oxides and hydroxides are available only as fine powders or are generated in aqueous suspensions as a hydroxide floc or gel. In these forms, they retain their desirable sorptive properties for various elements (Deliyanni et al. 2006).

One of the type of ferric products is akaganeite $(\beta$ $\mathrm{FeO}(\mathrm{OH})$ ). Akaganeite occurs in nature in hot brines of Atlantis Deep of the Red Sea and the hot springs of similar composition of the White Island volcano, New Zealand (Schwertmann and Cornell 2007). This mineral is formed in nature under the same conditions as these used in laboratory synthesis, i.e., in the presence of $\mathrm{FeCl}_{3}$ at elevated temperatures. Advantages of this adsorbent result from its nano-structured character, leading to high surface area and narrow pore size distribution (Deliyanni et al. 2003; Deliyanni et al. 2006; Deliyanni and Matis 2005). Akaganeite-based adsorbents have been successfully applied in recent years to remove inorganic arsenic species from drinking water (Kolbe et al. 2011). As the starting reagents for its synthesis are cheap and readily available, a potential application of akaganeite as an adsorbent can be recognized as economically efficient (Deliyanni et al. 2003). The mineral adsorbent can be modified by introducing onto its surface compounds revealing ionic character. For instance, hexadecyltrimethylammonium bromide (HDTMA) can modify chemically the surface of akaganeite at relatively small concentrations, as ionic surfactants are considered in general to sorb onto the surfaces of charged adsorbent by an ion exchange mechanism. The available data describing such materials provide the information about their suitability for the removal of As(III) species (Deliyanni et al. 2006). However, if the As(III) may be easily oxidized to ionic species of $\mathrm{As}(\mathrm{V})$, introduction of a surfactant can enhance adsorption of the so-prepared materials, increasing a role of ion exchange reactions acting during the process.

For this reason, the overall objective of this study was to determine whether surfactant modification of akaganeite is sufficient for enhancing adsorption of arsenic on such materials. The studies were carried out simultaneously for ferric oxide, pure akaganeite $(\beta$ $\mathrm{FeO}(\mathrm{OH}))(\mathrm{A})$, and its surfactant-modified derivative $\left(\mathrm{A}_{\mathrm{M}}\right)$. Within the present studies, total adsorption capacity, adsorption equilibrium, and adsorption kinetics were determined for these two adsorbents. The carried out analyses allowed to answer to questions: (1) Is the modification of hydrous ferric oxide with the HDTMA efficient? (2) Is such an approach enhancing adsorption of arsenic?

\section{Materials and Methods}

\subsection{Materials}

HDTMA was acquired from Alfa Aesar. The arsenic as well as $\mathrm{FeCl}_{3}$ and $\mathrm{NaOH}$ were purchased in Avantor Performance Materials Ltd. (Poland). All of the reagents were used as received, without pre-treatment. 


\subsection{Preparation of Akaganeite Adsorbent}

The preparation of akaganeite was carried out according to the method previously presented in the reference cited under Chitrakar et al. (2006). Two types of adsorbents were obtained: $(A)$ akaganeite and $\left(\mathrm{A}_{\mathrm{M}}\right)$ akaganeite modified with HDTMA.

The sample A was obtained as follows: a 2-L beaker containing $60 \mathrm{~mL}$ of $0.1 \mathrm{~mol} \mathrm{~L}^{-1} \mathrm{FeCl}_{3}$ solution was placed on a magnetic stirrer. Then, $0.1 \mathrm{~mol} \mathrm{~L}^{-1} \mathrm{NaOH}$ was slowly added, until the $\mathrm{pH}$ of the mixture reached a value of 10. After this, the content of the beaker was mixed for additional $1 \mathrm{~h}$; then, the so-prepared suspension was inserted in a cellulose dialysis membrane for 7 days to remove chlorine anions.

The sample $A_{M}$ was obtained applying the same procedure as described above with the difference that additionally $6 \mathrm{~mL}$ of $0.1 \mathrm{~mol} \mathrm{~L}^{-1}$ HDTMA solution was added drop-by-drop to the reacting mixture. The reaction product was then placed in a cellulose dialysis membrane for 7 days to remove chlorine anions.

\subsection{Methods}

Analysis of particle size was carried out using a Mastersizer 2000 laser diffractometer, equipped with HydroMu dispersion unit (Malvern Instruments). The specific surface areas of the akaganeite (A) and the modified akaganeite $\left(\mathrm{A}_{\mathrm{M}}\right)$ were determined by tests on sorption and desorption of helium/ nitrogen mixture using FlowSorb 2300 apparatus (Micromeritics). The received data were then recalculated using Brunauer-Emmett-Teller (BET) equation. The scanning electron microscope (SEM) micrographs were captured on a S-3400N microscope (HITACHI).

Concentration of As was analyzed spectrophotometrically using UV-Visible spectrophotometer Evolution 201 (Thermo Scientific) by means of the molybdenum blue method, according to appropriate standard procedure. Then, the adsorption $\left(\mathrm{mg} \mathrm{g}^{-1}\right)$ and arsenic removal (\%) were calculated from the initial and equilibrium concentrations determined after $24 \mathrm{~h}$ of the process (Giri et al. 2011).

Adsorption kinetics was modeled using a pseudosecond-order (PSO) and intraparticle pore diffusion (IPD) kinetic models in their linear forms (Ho and
McKay 1999; Shi et al. 2009; Ho et al. 2000), respectively:

$$
\frac{t}{q_{t}}=\frac{1}{k_{2} q_{m}^{2}}+\frac{t}{q_{m}}
$$

$q_{t}=k_{d}{ }^{1}{ }^{1} / 2+\theta$

where $k_{2}$ is the PSO rate constant $\left(\mathrm{g} \mathrm{mg}^{-1} \mathrm{~min}^{-1}\right), k_{d}$ is the IPD rate constant $\left(\mathrm{mg}\left(\mathrm{g}^{-1} \mathrm{~min}^{-1 / 2}\right)\right), q_{m}$ is the adsorption capacity at equilibrium $\left(\mathrm{mg} \mathrm{g}^{-1}\right)$, and $q_{t}$ is the amount of sorbate on the surface of the sorbent at any time $t\left(\mathrm{mg} \mathrm{g}^{-1}\right) . \Theta\left(\mathrm{mg} \mathrm{g}^{-1}\right)$ is a factor related to the thickness of the boundary layer; this value is proportional to boundary layer effect.

Equilibrium studies were carried out by fitting the experimental data to the linearized Langmuir equation:

$\frac{c_{e q}}{q_{e}}=\frac{1}{Q_{0} b}+\frac{c_{e q}}{Q_{0}}$

The separation factor (dimensionless) called equilibrium or separation parameter $\left(R_{L}\right)$ was calculated from the equation:

$R_{L}=\frac{1}{1+b c_{0}}$

where $c_{0}$ is the initial concentration of As $\left(\mathrm{mg} \mathrm{L}^{-1}\right), c_{\mathrm{eq}}$ is the equilibrium concentration $\left(\mathrm{mg} \mathrm{L}^{-1}\right), q_{e}$ is the experimental adsorption capacity at equilibrium $\left(\mathrm{mg} \mathrm{g}^{-1}\right), Q_{0}$ is the adsorption capacity $\left(\mathrm{mg} \mathrm{g}^{-1}\right)$, and $b$ is the Langmuir adsorption constant related to the adsorption energy $\left(\mathrm{L} \mathrm{mg}^{-1}\right)$.

\subsection{Adsorption of As}

Arsenic trioxide $\left(\mathrm{As}_{2} \mathrm{O}_{3}\right)$ was used as the source of As ions. A stock solution (1000 $\mathrm{mg} \mathrm{L}^{-1}$ ) was prepared in deionized water in the presence of $\mathrm{NaOH}$. The soprepared solution was acidified with $2.0 \mathrm{~mol} \mathrm{~L}^{-1} \mathrm{HCl}$ (pH 3 ) and diluted to $1 \mathrm{~L}$ with deionized water.

All the adsorption studies were carried out using batch method at room temperature and $\mathrm{pH} 7$ for $24 \mathrm{~h}$. The effect of $\mathrm{pH}$ was investigated by adjusting the $\mathrm{pH}$ of a set of As solutions using $0.1 \mathrm{M} \mathrm{HCl}$ and $0.1 \mathrm{M} \mathrm{NaOH}$, respectively. Then, $11 \mathrm{mg}$ of an adsorbent $\left(\mathrm{A}\right.$ or $\left.\mathrm{A}_{\mathrm{M}}\right)$ per each $10 \mathrm{~mL}$ of a solution was taken. The effect of adsorbent dose was studied by varying the dose of an adsorbent (A or $\mathrm{A}_{\mathrm{M}}$ ) from 1.1 to $55 \mathrm{mg}$ for initial As 
concentration of $100 \mathrm{mg} \mathrm{L}^{-1}$. The equilibrium studies of As adsorption were carried out using $11 \mathrm{mg}$ of an adsorbent, introduced into $10 \mathrm{~mL}$ of As solutions that concentration was varied in range of $20-250 \mathrm{mg} \mathrm{L}^{-1}$. The kinetic experiments were conducted in batch mode by shaking $11 \mathrm{mg}$ of an adsorbent with As solution at a constant $\mathrm{pH}(\sim 7)$. As concentration was monitored for $3 \mathrm{~h}$, starting from third minute of the process.

\section{Results and Discussion}

\subsection{Characterization of Adsorbents}

In Table 1, the particle size analysis of pure akaganeite showed volume median diameter $\left(d_{50}\right)$ of $22.0 \mu \mathrm{m}$, while the same parameter determined for the modified akaganeite was $28.7 \mu \mathrm{m}$. The corresponding values of $d_{10}$ and $d_{90}$ were also higher in the case of the sample $\mathrm{A}_{\mathrm{M}}$ (Table 1). The phenomenon must had been caused by the effect of surfactant (HDTMA) addition to the mixture which the adsorbent $\left(\mathrm{A}_{\mathrm{M}}\right)$ was precipitated from. The presence of the surface-active agent simply allowed bigger agglomerates to be obtained. Substantial differences can be observed in the specific surface areas of both samples. They are, respectively, 254.0 (A) and $26.0 \mathrm{~m}^{2} \mathrm{~g}\left(\mathrm{~A}_{\mathrm{M}}\right)$. Such a ten-fold difference may indicate that the HDTMA filled up the pores of the akaganeite; thus, the modification might indeed occur.

Morphology of the obtained adsorbents was investigated by scanning electron microscopy (SEM). The captured micrographs are displayed in Fig. 1.

As can be seen in Fig. 1, unmodified akaganeite is characterized by uniform compact structure, while on the surface of the HDTMA-modified one supports longitudinal particles, previously recognized as an indicator of mineral modification using surfactant (Deliyanni et al. 2006).

Table 1 Characteristics of the obtained samples

\begin{tabular}{llrrr}
\hline Sample & $d_{50}{ }^{\mathrm{a}}$ & \multicolumn{1}{c}{$d_{10}{ }^{\mathrm{a}}$} & $d_{90}{ }^{\mathrm{a}}$ & $S_{\mathrm{BET}}{ }^{\mathrm{b}}$ \\
\hline $\mathrm{A}$ & 22.02 & 8.35 & 48.34 & 254 \\
$\mathrm{~A}_{\mathrm{M}}$ & 28.72 & 10.02 & 62.34 & 26 \\
\hline
\end{tabular}

A pure akaganeite, $A_{M}$ modified akaganeite

${ }^{\text {a }}$ Diameter percentile $(\mu \mathrm{m})$

${ }^{\mathrm{b}}$ Specific surface area $\left(\mathrm{m}^{2} \mathrm{~g}^{-1}\right)$

\subsection{Effect of Adsorbent Dosage}

Figures 2 and 3 display the effect of adsorbent dose on the removal of As. The maximum static uptake of As by the samples $A$ and $A_{M}$ was achieved for minimal possible adsorbent-to-solute ratio of $0.11 \mathrm{mg} / \mathrm{mL}$ and were 190.9 and $198.1 \mathrm{mg} \mathrm{g}^{-1}$, respectively. The maximum removal of As was achieved for maximal dose of adsorbent (above 90\%). The obtained results are interesting, as already reported in the literature maximum values of adsorption for different ions on akaganeite are for instance $0.65 \mathrm{mg} \mathrm{g}^{-1}$ of antimony (Kolbe et al. 2011), $10 \mathrm{mg} \mathrm{g}^{-1}$ of phosphates (Chitrakar et al. 2006), $80 \mathrm{mg} \mathrm{g}^{-1}$ of chromium (VI) (Lazaridis et al. 2005), and $17.1 \mathrm{mg} \mathrm{g}^{-1}$ of cadmium (Deliyanni and Matis 2005).

\subsection{Effect of $\mathrm{pH}$}

The samples $A$ and $A_{M}$ were contacted with solutions that $\mathrm{pH}$ has varied in range from 2.4 to 10 . Figure 4 displays effect of $\mathrm{pH}$ on the adsorption of As. It was observed that As adsorption increases with the increase of solution $\mathrm{pH}$ to about 8. However, the adsorption of As decreases slightly when solution $\mathrm{pH}>8.5$. The maximum removal of As occurs at $\mathrm{pH} 7-8.5$, in which the removal percentage was more than $45 \%$ for the sample $A_{M}$. The sample $A_{M}$ reveals an overall greater sorption capacity that the unmodified mineral, except of $\mathrm{pH}$ 5.4, where adsorption capacity is almost equal for both samples. The effect must be attributed to the presence of quaternary ammonium groups in the sample $\mathrm{A}_{\mathrm{M}}$. In both acidic or basic $\mathrm{pH}$, the functionalities are bearing exchangeable ions $\left(\mathrm{Cl}^{-}\right.$or $\left.\mathrm{OH}^{-}\right)$, while at neutral $\mathrm{pH}$, it exists in form of free amine. This further can be linked with speciation of As, as the metal exists in ionic forms at $\mathrm{pH}$ between 7 and 8 (Takeno 2005). For this reason, it can be assumed that adsorption on the sample $A_{M}$ may employ an ionexchange mechanism. This could also explain why the removal efficiency is not dependent on specific surface area (which is ten times higher in case of the sample A). Hence, the adsorption of As on the modified iron oxide may reveal a chemical character. For this reason, the further adsorption studies were carried out at natural $\mathrm{pH}$ (7) of the solutions (see Sect. 2).

\subsection{Adsorption Kinetics}

As shown in Fig. 5, the As adsorption onto iron oxides is considerably fast during the initial period of the process. 

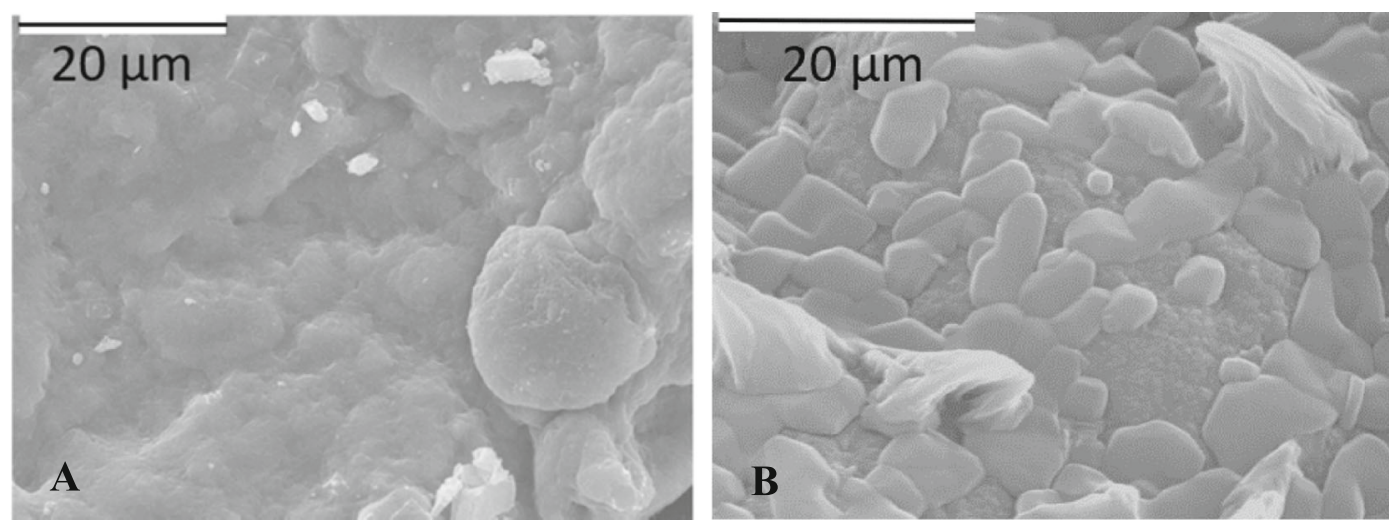

Fig. 1 SEM micrographs of a akaganeite and $\mathbf{b}$ akaganeite modified with HDTMA

Adsorption equilibrium was reached after $90 \mathrm{~min}$. It is worth mentioning that the modification of akaganeite with HDTMA improved its sorption capacity.

Within the present studies, kinetics of the adsorption of As was modeled using pseudo-second-order kinetic model (PSO) in its linear form (Eq. 1). The model provides good correlation of the experimental data in many cases (Mohan and Pittman 2007; Mostafa et al. 2011; Sarı and Tuzen 2009). The values of $k_{2}$ and $q_{m}$ were calculated from the slope and intercept of the $t / q_{t}$ versus $t$ plots, respectively. Additionally, initial adsorption rate $\left(\mathrm{mg} \mathrm{g}^{-1} \mathrm{~min}^{-1}\right)$ defined as $h=k_{2} q_{m}^{2}$ was calculated. The resultant values are summarized in Table 2 . Values of the correlation coefficients $\left(R^{2}\right)$ are close to 1 , indicating that the model complies with the experimental adsorption capacity; thus, the model is selected properly for the present studies. The calculated adsorption capacities $\left(q_{m}\right)$ are similar to the experimental ones

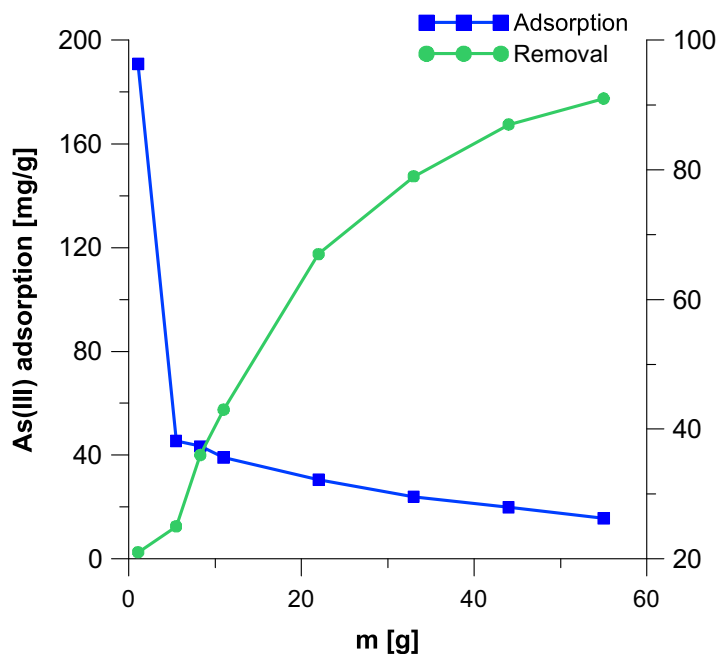

Fig. 2 The adsorption capacity of akaganeite towards As
( $\left.q_{\text {exp }}\right)$; however, pseudo-second-order rate constant $\left(k_{2}\right)$ is over twice lower in the case of the modified iron oxide $\left(A_{M}\right)$, which is probably directly correlated with the significant difference between initial adsorption rates ( $h$; Table 2). This can indicate that the internal surface area (Table 1) of the sample $A_{M}$, which is developed to a lesser extent than in the case of the unmodified mineral A, can cause diffusional limitations experienced by the adsorbate. For this reason, an intraparticle pore diffusion kinetic model (IPD) was also applied to the present results.

Figure 6 displays plots of IPD kinetic model applied for the adsorption of As on the iron oxides, while Table 3 provides parameters calculated using thereof.

As can be seen in Fig. 6, the adsorption of As on both adsorbents is a two-stage process. The rates of the first stages are assigned to the macropore and mesopore

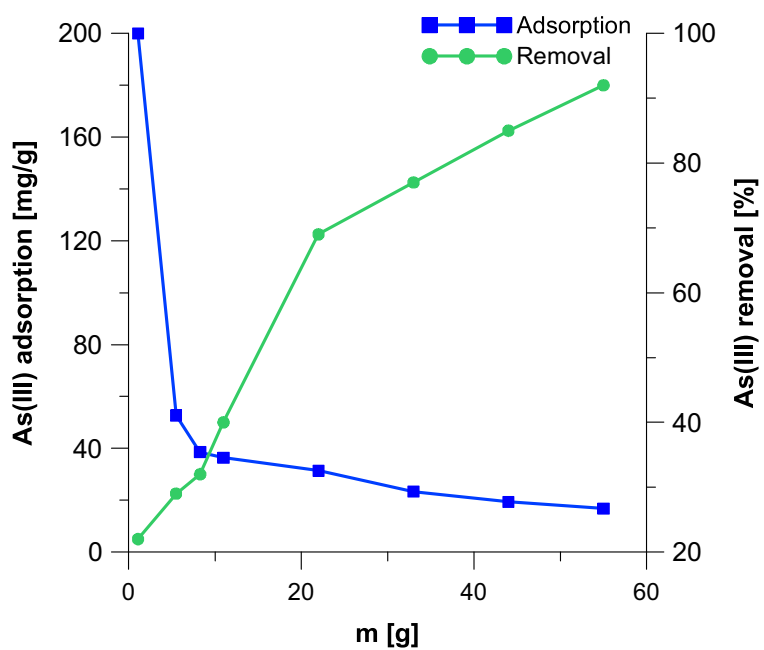

Fig. 3 The adsorption capacity of modified akaganeite and As removal 


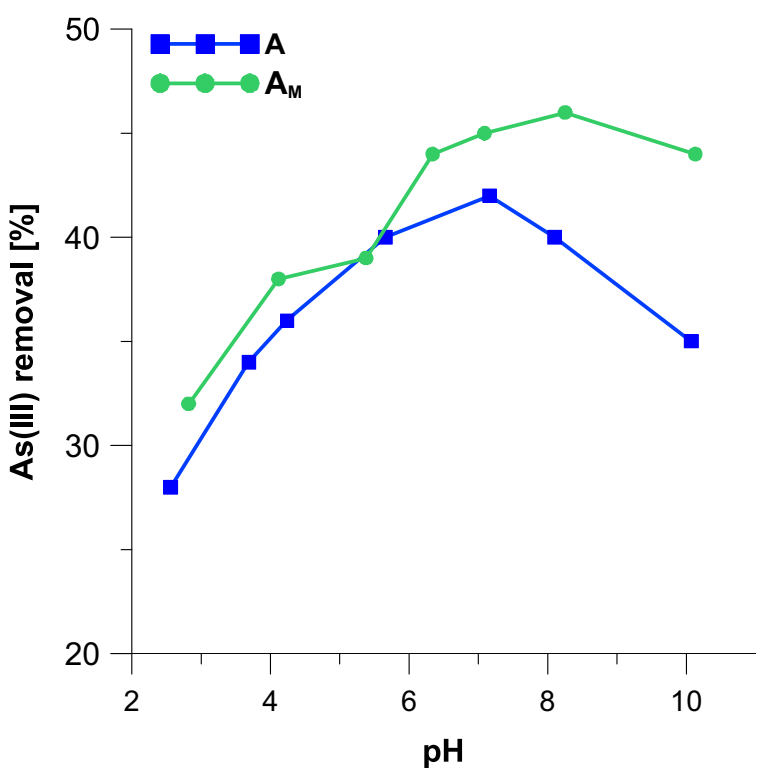

Fig. 4 Effect of solution $\mathrm{pH}$ on As adsorption onto akaganeite (A) and modified akaganeite $\left(\mathrm{A}_{\mathrm{M}}\right)$

diffusion (Fierro et al. 2008). Contrary to the PSO model, the IPD adsorption rate in the initial stage of adsorption is over twice greater in the case of the modified sample $\left(k_{d}\right.$; Table 3$)$. The phenomenon is surprising, as the film diffusion should be much easier in the case of pure akaganeite which internal surface area is much more developed. However, the PSO kinetics considers initial state of the process as a whole, from its

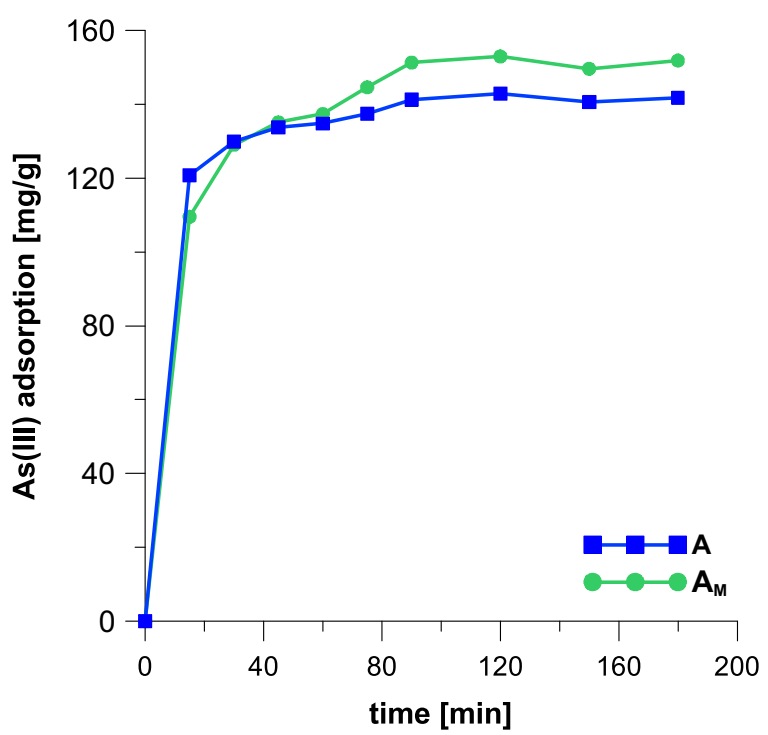

Fig. 5 Kinetics of As adsorption onto akaganeite (A) and modified akaganeite $\left(\mathrm{A}_{\mathrm{M}}\right)$
Table 2 PSO kinetic model parameters calculated for the adsorption of As

\begin{tabular}{llllll}
\hline Sample & $q_{\exp }{ }^{\mathrm{a}}$ & $q_{m}{ }^{\mathrm{b}}$ & $k_{2}{ }^{\mathrm{c}}$ & $h^{\mathrm{d}}$ & $R^{2}$ \\
\hline $\mathrm{A}$ & 142.8 & 144.7 & $2.07 \times 10^{-3}$ & 43.3 & 0.9997 \\
$\mathrm{~A}_{\mathrm{M}}$ & 153.0 & 158.3 & $0.92 \times 10^{-3}$ & 23.0 & 0.9990 \\
\hline
\end{tabular}

$A$ akaganeite, $A_{M}$ modified akaganeite

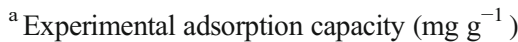

${ }^{\mathrm{b}}$ Adsorption capacity received form PSO equation (Eq. 1) $\left(\mathrm{mg} \mathrm{g}^{-1}\right)$

${ }^{\mathrm{c}}$ PSO rate constant $\left(\mathrm{g} \mathrm{mg}^{-1} \mathrm{~min}^{-1}\right)$

${ }^{\mathrm{d}}$ Initial adsorption rate $\left(\mathrm{mg} \mathrm{g}^{-1} \mathrm{~min}^{-1}\right)$

beginning to the end, while IPD model is focused on film diffusion, not taking into account adsorption at time equal to 0 .

The values collected within Table 3 indicate that adsorption of arsenic on the both samples reveal a complex character. As already reported in the literature (Deliyanni et al. 2006), the adsorption on iron oxides involves an electron transfer from $\mathrm{Fe}$ and $\mathrm{O}$ atoms; thus, it reveals chemical character. However, as displayed in Table 3, the value of $\Theta$ which is the measure of a theoretical boundary layer thickness is smaller in the case of the modified akaganeite. This could mean that HDTMA makes the mineral surface more accessible for the adsorbate. Hence, the greater efficiency of the sample $A_{M}$ is observed.

\subsection{Equilibrium Studies}

The obtained As adsorption isotherms expressed as adsorption capacity in function of equilibrium concentration are displayed in Fig. 7.

The experimental data were recalculated using with Langmuir equation (Eq. 3), as predictably most suitable model in the present studies (Deliyanni et al. 2003; Deliyanni and Matis 2005; Mostafa et al. 2011; Pirilä et al. 2011). Values of $Q_{0}$ and $b$ were calculated from the slope and intercept of the linear plot of $c_{\mathrm{eq}} / q_{e}$ versus $c_{\mathrm{eq}}$, respectively. The Langmuir constants and parameters (Eq. 3) are listed in Table 4.

The essential characteristic of the Langmuir isotherm can be represented by the parameter $R_{L}$ which demonstrates the shape of the isotherm. If $R_{L}$ is higher than 1 , the adsorption is unfavorable. If $R_{L}$ is equal to 1 , the adsorption is linear. If the parameter $R_{L}$ has value lying in the range of 0 to 1 , the adsorption can be described as 

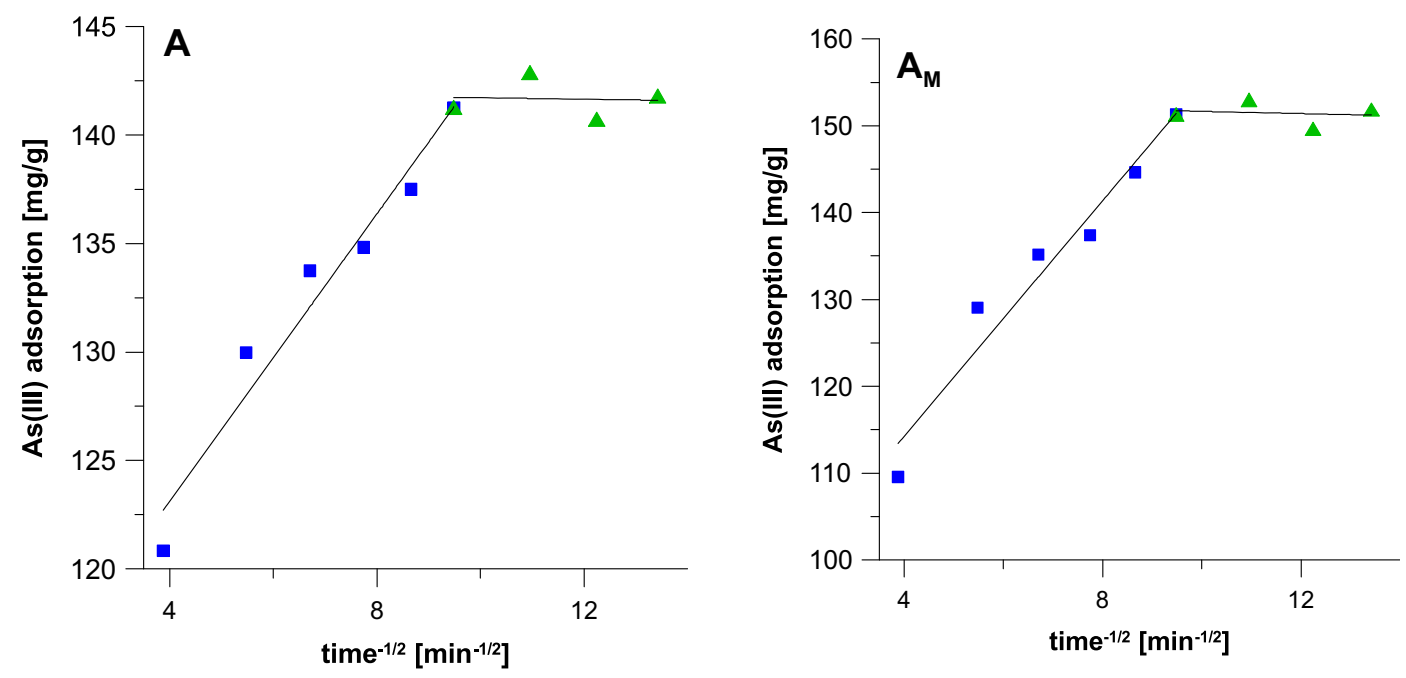

Fig. 6 Intraparticle pore diffusion kinetic model applied for adsorption of As on (A) akaganeite and $\left(\mathrm{A}_{\mathrm{M}}\right)$ modified iron oxide

favorable. If $R_{L}$ is equal to 0 , the adsorption is irreversible (Öztürk and Kavak 2005). As displayed in Table 2, the values of $R_{L}$ are very small but lying in the range of 0 to 1 ; therefore, the adsorption of As onto akaganeitetype adsorbents is a favorable process. The $R_{L}$ values vary in the range, respectively, $0.03-0.65(\mathrm{~A})$ and 0.04 $0.71\left(\mathrm{~A}_{\mathrm{M}}\right)$. These values decrease when initial concentration of a solution increases.

The $Q_{0}$ values determined for the samples $\mathrm{A}$ and $\mathrm{A}_{\mathrm{M}}$ are comparable (Table 2) despite ten-fold difference between the BET surface area (Table 1) of these adsorbents. This observation confirms that the efficiency of adsorption is not linked with porous structure of the obtained samples. As far as the process complied with Langmuir model (high values of $R^{2}$; Table 2), a conclusion that the adsorbate creates monolayer on the surface of adsorbent, thus it reveals chemical character, can be made. The problem is that As species are neutral at $\mathrm{pH}$ between 6 and 9 (Yazdi and Darban), while the present studies were carried out at $\mathrm{pH} 7$. If the investigated adsorption mechanism reveals chemical character, the initial As(III) must had been oxidized to $\mathrm{As}(\mathrm{V})$ at $\mathrm{pH} 7$. The phenomenon is often reported in literature data, as the $\mathrm{As}(\mathrm{III})$ is unstable at higher $\mathrm{pH}$ (Yazdi and Darban;

Table 3 Parameters of IPD kinetic model

${ }^{\mathrm{a}}$ IPD rate constant $\left(\mathrm{mg}\left(\mathrm{g}^{-1} \mathrm{~min}^{-1 / 2}\right)\right)$

${ }^{\mathrm{b}}$ Measure of boundary layer thickness $\left(\mathrm{mg} \mathrm{g}^{-1}\right)$

\begin{tabular}{llrr}
\hline Sample $^{\mathrm{a}}$ & \multicolumn{4}{l}{ First stage } \\
\cline { 2 - 4 } & $k_{d}^{\mathrm{a}}$ & $\Theta^{\mathrm{b}}$ & $R^{2}$ \\
\hline $\mathrm{A}$ & 3.1 & 109.9 & 0.95 \\
$\mathrm{~A}_{\mathrm{M}}$ & 6.8 & 87.1 & 0.95 \\
\hline
\end{tabular}

Takeno 2005). At pH above 6, the As(III) species oxidizes to $\mathrm{As}(\mathrm{V})$, appearing in the ionic form of $\mathrm{HAsO}_{4}{ }^{2-}$ (Takeno 2005). However, as indicated before (Deliyanni et al. 2006), the mechanism of arsenic adsorption does not involve ion exchange on the quaternary ammonium group introduced together with HDTMA, but on the surface of iron oxide itself. Therefore, the reason of the greater adsorption capacity registered for the sample $A_{M}$ should be found in the parameters of the applied IPD kinetic model as described above. The value of $\Theta$ (Table 3), which is the measure of theoretical boundary layer thickness, is greater in the case of the modified iron

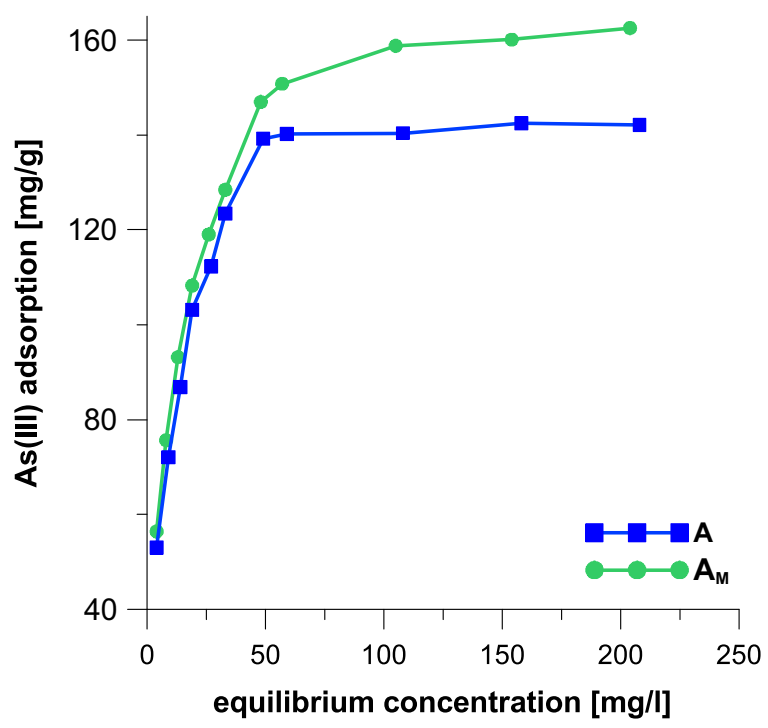

Fig. 7 Adsorption of As on akaganeite (A) and modified akaganeite $\left(\mathrm{A}_{\mathrm{M}}\right)$ 
Table 4 Parameters and $R^{2}$ values for the Langmuir model

\begin{tabular}{llllll}
\hline Sample & $Q_{0}{ }^{\mathrm{a}}$ & $b^{\mathrm{b}}$ & $R^{2}$ & $\begin{array}{l}R_{L} \text { (initial } \\
\text { concentration: } 4 \mathrm{mg} \mathrm{L}{ }^{-1} \text { ) }\end{array}$ & $\begin{array}{l}R_{L} \text { (initial concentration: } \\
250 \mathrm{mg} \mathrm{L}^{-1} \text { ) }\end{array}$ \\
\hline $\mathrm{A}$ & 148.7 & 0.1365 & 1.00 & 0.65 & 0.03 \\
$\mathrm{~A}_{\mathrm{M}}$ & 170.9 & 0.1033 & 1.00 & 0.71 & 0.04 \\
\hline
\end{tabular}

$A$ akaganeite, $A_{M}$ modified akaganeite

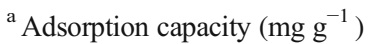

${ }^{\mathrm{b}}$ Langmuir adsorption constant $\left(\mathrm{L} \mathrm{mg}^{-1}\right)$

oxide. The phenomenon is directly attributed to the impact of the HDTMA introduced into adsorbent, as the quaternary ammonium group affects the charge on $\mathrm{Fe}-$ and O-containing functional groups present in the akaganeite. This further makes the diffusion of arsenic within the adsorbent easier (Deliyanni et al. 2006). Within the present studies, we postulate that the phenomenon makes the active sites more accessible, thus improving adsorption capacity of the so-prepared adsorbent.

\subsection{Presented Iron Oxides Versus Adsorbents Reported in Literature}

Table 5 displays comparison of the adsorption capacities of arsenic adsorbents investigated in the present studies to other ones reported in the worldwide literature.

Based on the already reported solutions, the adsorption of arsenic on low-cost adsorbents varies from 0.3 to
$134 \mathrm{mg} \mathrm{g}^{-1}$. As can be seen in Table 5, application of waste materials can be attractive, as adsorption of $\mathrm{As}(\mathrm{III})$ and $\mathrm{As}(\mathrm{V})$ is comparable or even grater to the corresponding processes carried out on zeolites and alumina-based adsorbents. Based on the data collected in the literature, as well as these presented in the present work, it can be concluded that application of mineral iron-oxide adsorbents reveals superiority of such a solution. As far as removal of arsenic on the pure akaganeite is comparable to the capacity of similar mineral reported by Deliyanni (Deliyanni et al. 2003), the modification thereof indeed improved adsorption of As. Removal of arsenic in fixed conditions for the sample $A_{M}$ was approximately $30 \mathrm{mg} \mathrm{g}^{-1}$ greater than these received for unmodified iron oxides (Table 5). It must be also emphasized that when an excess of arsenic is applied during the process, the maximum adsorption capacity on the sample $A_{M}$ can be further increased to $200 \mathrm{mg} \mathrm{g}^{-1}$ (see Fig. 3), making the reported
Table 5 Synthetic iron oxides compared to other adsorbents of arsenic

\begin{tabular}{llll}
\hline Adsorbent & Pollutants & $Q_{\max }\left(\mathrm{mg} \mathrm{g}^{-1}\right)$ & References \\
\hline Mesoporous $\gamma$-alumina & As(V) & 19.1 & Tchieda et al. (2016) \\
Zeolite (H24) & As(V) & 35.8 & Chutia et al. (2009) \\
Macrofungus biomass & As(V) & 59.6 & Sarı and Tuzen (2009) \\
& As(III) & 51.9 & \\
Biogenic schwertmannite & As(III) & 113.9 & Liao et al. (2011) \\
Soot & As(V) & 30.5 & Pattanayak et al. (2000) \\
Fly ash & As(III) & 29.9 & \\
Fly ash & As(V) & 30.0 & Diamadopoulos et al. (1993) \\
Iron oxide coated cement & As(III) & 74.4 & Polowczyk et al. (2010) \\
Akaganeite & As(III) & 0.3 & Kundu and Gupta (2007) \\
Akaganeite & As(V) & 134.1 & Deliyanni et al. (2003) \\
Akaganeite modified & As(III) & 148.7 & Present studies \\
\hline
\end{tabular}


modification of akaganeite a very attractive solution for enhancing processes of As removal.

\section{Conclusion}

Within the present studies, the As adsorption on akaganeite (A) and akaganeite modified with HDTMA was assessed. Based on the obtained data, the following conclusions can be made:

- Comparing to literature data, both the akaganeite (A) and the surfactant-modified akaganeite $\left(\mathrm{A}_{\mathrm{M}}\right)$ are very efficient adsorbents for As removal.

- Modification of akaganeite resulted in significant decrease of its specific surface area, indicating that the HDTMA was indeed immobilized within structure of the mineral.

- The akaganeite modified with HDTMA reveals greater adsorption capacity, thus the ability to remove As.

- Although the modification of akaganeite did improve its adsorption capacity, the present studies also revealed that As loading capacity is not dependent on the porous structure of these materials.

- Introduction of HDTMA into the iron oxide decreases the thickness of theoretical boundary layer; hence, its positive effect on adsorption capacity is observed.

- Because the As adsorption complies with Langmuir and PSO models and no linkage with specific surface area was found, it can be stated that the process reveals a chemical character.

- Based on the IPD kinetic model, it can be stated that the thickness of the theoretical boundary layer is smaller in the case of the modified mineral; thus, the diffusion is enhanced.

- Adsorption of As on iron oxides should be carried out at $\mathrm{pH}$ around 7.5 as the speciation of As favors chemical adsorption.

Acknowledgements This work was supported by Polish Ministry of Science and Higher Education from the funds granted Wroclaw University of Science and Technology for statutory activity.

Open Access This article is distributed under the terms of the Creative Commons Attribution 4.0 International License (http:// creativecommons.org/licenses/by/4.0/), which permits unrestricted use, distribution, and reproduction in any medium, provided you give appropriate credit to the original author(s) and the source, provide a link to the Creative Commons license, and indicate if changes were made.

\section{References}

Aguilar-Carrillo, J., Garrido, F., Barrios, L., \& García-González, M. T. (2006). Sorption of As, Cd and $\mathrm{Tl}$ as influenced by industrial by-products applied to an acidic soil: Equilibrium and kinetic experiments. Chemosphere, 65(11), 2377-2387. https://doi.org/10.1016/j.chemosphere.2006.04.092.

Anderson, M. A., Ferguson, J. F., \& Gavis, J. (1976). Arsenate adsorption on amorphous aluminum hydroxide. Journal of Colloid and Interface Science, 54(3), 391-399. https://doi. org/10.1016/0021-9797(76)90318-0.

Chitrakar, R., Tezuka, S., Sonoda, A., Sakane, K., Ooi, K., \& Hirotsu, T. (2006). Phosphate adsorption on synthetic goethite and akaganeite. Journal of Colloid and Interface Science, 298(2), 602-608. https://doi.org/10.1016/j.jcis.2005.12.054.

Cho, H., Oh, D., \& Kim, K. (2005). A study on removal characteristics of heavy metals from aqueous solution by fly ash. Journal of Hazardous Materials, 127(1), 187-195. https://doi.org/10.1016/j.jhazmat.2005.07.019.

Choong, T. S. Y., Chuah, T. G., Robiah, Y., Gregory Koay, F. L., \& Azni, I. (2007). Arsenic toxicity, health hazards and removal techniques from water: An overview. Desalination, 217(1), 139-166. https://doi.org/10.1016/j.desal.2007.01.015.

Chutia, P., Kato, S., Kojima, T., \& Satokawa, S. (2009). Adsorption of as(V) on surfactant-modified natural zeolites. Journal of Hazardous Materials, 162(1), 204-211. https://doi.org/10.1016/j.jhazmat.2008.05.024.

Deliyanni, E. A., \& Matis, K. A. (2005). Sorption of cd ions onto akaganéite-type nanocrystals. Separation and Purification Technology, 45(2), 96-102. https://doi.org/10.1016/j. seppur.2005.02.012.

Deliyanni, E. A., Bakoyannakis, D. N., Zouboulis, A. I., \& Matis, K. A. (2003). Sorption of as(V) ions by akaganéite-type nanocrystals. Chemosphere, 50(1), 155-163. https://doi. org/10.1016/S0045-6535(02)00351-X.

Deliyanni, E. A., Nalbandian, L., \& Matis, K. A. (2006). Adsorptive removal of arsenites by a nanocrystalline hybrid surfactantakaganeite sorbent. Journal of Colloid and Interface Science, 302(2), 458-466. https://doi.org/10.1016/j.jcis.2006.07.007.

Diamadopoulos, E., Ioannidis, S., \& Sakellaropoulos, G. P. (1993). As(V) removal from aqueous solutions by fly ash. Water Research, 27(12), 1773-1777. https://doi.org/10.1016 /0043-1354(93)90116-Y.

Fierro, V., Torne-Fernandez, V., Montane, D., \& Celzard, A. (2008). Adsorption of phenol onto activated carbons having different textural and surface properties. Microporous and Mesoporous Materials, 111, 276-284.

Giri, A. K., Patel, R. K., \& Mahapatra, S. S. (2011). Artificial neural network (ANN) approach for modelling of arsenic (III) biosorption from aqueous solution by living cells of Bacillus cereus biomass. Chemical Engineering Journal, 178(Supplement C), 15-25. https://doi.org/10.1016/j.cej.2011.09.111.

Guo, H., Li, Y., Zhao, K., Ren, Y., \& Wei, C. (2011). Removal of arsenite from water by synthetic siderite: Behaviors and mechanisms. Journal of Hazardous Materials, 186(2), 1847-1854. https://doi.org/10.1016/j.jhazmat.2010.12.078.

Gupta, V.K., \& Nayak, A. (2012). Cadmium removal and recovery from aqueous solutions by novel adsorbents prepared from orange peel and Fe2O3 nanoparticles. Chemical Engineering Journal, 180, 81-90. https://doi.org/10.1016/j.cej.2011.11.006. 
Gupta, V. K., \& Saleh, T. A. (2013). Sorption of pollutants by porous carbon, carbon nanotubes and fullerene- an overview. [journal article]. Environmental Science and Pollution Research, 20(5), 2828-2843. https://doi.org/10.1007 /s11356-013-1524-1.

Ho, Y. S., \& McKay, G. (1999). Pseudo-second order model for sorption processes. Process Biochemistry, 44, 451-456.

Ho, Y. S., Ng, J. C. Y., \& McKay, G. (2000). Kinetics of pollutant sorption by biosorbents: Review. Separation and Purification Reviews, 29, 189-232.

Kim, J., \& Benjamin, M. M. (2004). Modeling a novel ion exchange process for arsenic and nitrate removal. Water Research, 38(8), 2053-2062. https://doi.org/10.1016/j. watres.2004.01.012.

Kolbe, F., Weiss, H., Morgenstern, P., Wennrich, R., Lorenz, W., Schurk, K., et al. (2011). Sorption of aqueous antimony and arsenic species onto akaganeite. Journal of Colloid and Interface Science, 357(2), 460-465. https://doi.org/10.1016 /j.jcis.2011.01.095.

Kundu, S., \& Gupta, A. K. (2007). As(III) removal from aqueous medium in fixed bed using iron oxide-coated cement (IOCC): Experimental and modeling studies. Chemical Engineering Journal, 129(1), 123-131. https://doi. org/10.1016/j.cej.2006.10.014.

Lazaridis, N. K., Bakoyannakis, D. N., \& Deliyanni, E. A. (2005). Chromium(VI) sorptive removal from aqueous solutions by nanocrystalline akaganèite. Chemosphere, 58(1), 65-73. https://doi.org/10.1016/j.chemosphere.2004.09.007.

Liao, Y., Liang, J., \& Zhou, L. (2011). Adsorptive removal of as(III) by biogenic schwertmannite from simulated ascontaminated groundwater. Chemosphere, 83(3), 295-301. https://doi.org/10.1016/j.chemosphere.2010.12.060.

Mohan, D., \& Pittman, C. U. (2007). Arsenic removal from water/ wastewater using adsorbents-A critical review. Journal of Hazardous Materials, 142, 1), 1-1),53. https://doi. org/10.1016/j.jhazmat.2007.01.006.

Mohan, D., Pittman, C. U., Bricka, M., Smith, F., Yancey, B., Mohammad, J., et al. (2007). Sorption of arsenic, cadmium, and lead by chars produced from fast pyrolysis of wood and bark during bio-oil production. Journal of Colloid and Interface Science, 310(1), 57-73. https://doi.org/10.1016/j. jcis.2007.01.020.

Mostafa, M. G., Chen, Y.-H., Jean, J.-S., Liu, C.-C., \& Lee, Y.-C. (2011). Kinetics and mechanism of arsenate removal by nanosized iron oxide-coated perlite. Journal of Hazardous Materials, 187(1), 8995. https://doi.org/10.1016/j.jhazmat.2010.12.117.

Ning, R. Y. (2002). Arsenic removal by reverse osmosis. Desalination, 143(3), 237-241. https://doi.org/10.1016 /S0011-9164(02)00262-X.

Öztürk, N., \& Kavak, D. (2005). Adsorption of boron from aqueous solutions using fly ash: Batch and column studies. Journal of Hazardous Materials, 127(1), 81-88. https://doi. org/10.1016/j.jhazmat.2005.06.026.

Pakzadeh, B., \& Batista, J. R. (2011). Surface complexation modeling of the removal of arsenic from ion-exchange waste brines with ferric chloride. Journal of Hazardous Materials, 188(1), 399407. https://doi.org/10.1016/j.jhazmat.2011.01.117.

Pattanayak, J., Mondal, K., Mathew, S., \& Lalvani, S. B. (2000). A parametric evaluation of the removal of as(V) and as(III) by carbon-based adsorbents. Carbon, 38(4), 589-596. https://doi.org/10.1016/S0008-6223(99)00144-X.
Pirilä, M., Martikainen, M., Ainassaari, K., Kuokkanen, T., \& Keiski, R. L. (2011). Removal of aqueous as(III) and as(V) by hydrous titanium dioxide. Journal of Colloid and Interface Science, 353(1), 257-262. https://doi.org/10.1016 j.j.jis.2010.09.020.

Polowczyk, I., Bastrzyk, A., Koźlecki, T., Sawiński, W., Rudnicki, P., Sokołowski, A., et al. (2010). Use of fly ash agglomerates for removal of arsenic. [journal article]. Environmental Geochemistry and Health, 32(4), 361-366. https://doi. org/10.1007/s10653-010-9306-X.

Saleh, T. A., Agarwal, S., \& Gupta, V. K. (2011). Synthesis of MWCNT/MnO2 and their application for simultaneous oxidation of arsenite and sorption of arsenate. Applied Catalysis B: Environmental, 106(1), 46-53. https://doi.org/10.1016/j. apcatb.2011.05.003.

Sar1, A., \& Tuzen, M. (2009). Biosorption of as(III) and as(V) from aqueous solution by macrofungus (Inonotus hispidus) biomass: Equilibrium and kinetic studies. Journal of Hazardous Materials, 164(2), 1372-1378. https://doi. org/10.1016/j.jhazmat.2008.09.047.

Schwertmann, U., \& Cornell, R. M. (2007). Akaganéite. In Iron Oxides in the Laboratory (pp. 113-119): Wiley-VCH Verlag GmbH.

Sharma, V. K., \& Sohn, M. (2009). Aquatic arsenic: Toxicity, speciation, transformations, and remediation. Environment International, 35(4), 743-759. https://doi.org/10.1016/j. envint.2009.01.005.

Shi, K., Wang, X., Guo, Z., Wang, S., \& Wu, W. (2009). Se(IV) sorption on $\mathrm{TiO}_{2}$ : Sorption kinetics and surface complexation modeling. Colloids and Surfaces A, 349, 90-95.

Smedley, P. L., \& Kinniburgh, D. G. (2002). A review of the source, behaviour and distribution of arsenic in natural waters. Applied Geochemistry, 17(5), 517-568. https://doi. org/10.1016/S0883-2927(02)00018-5.

Song, S., Lopez-Valdivieso, A., Hernandez-Campos, D. J., Peng, C., Monroy-Fernandez, M. G., \& Razo-Soto, I. (2006). Arsenic removal from high-arsenic water by enhanced coagulation with ferric ions and coarse calcite. Water Research, 40(2), 364-372. https://doi.org/10.1016/j.watres.2005.09.046.

Takeno, N. (2005). Geological Survey of Japan, Atlas of Eh-pH Diagrams, Geological Survey of Japan Open File Report No. 419: National Institute of Advanced Industrial Science and Technology Research Center for Deep Geological Environments.

Tchieda, V. K., Emilio, D. A., Agostina, C., Mariapaola, P., Angelo, C., Mohamed, A., et al. (2016). Removal of arsenic by alumina: Effects of material size, additives, and water contaminants. CLEAN - Soil, Air, Water, 44(5), 496-505. https://doi.org/10.1002/clen.201400599.

Wang, S., \& Mulligan, C. N. (2008). Speciation and surface structure of inorganic arsenic in solid phases: A review. Environment International, 34(6), 867-879. https://doi. org/10.1016/j.envint.2007.11.005.

Wickramasinghe, S. R., Han, B., Zimbron, J., Shen, Z., \& Karim, M. N. (2004). Arsenic removal by coagulation and filtration: Comparison of groundwaters from the United States and Bangladesh. Desalination, 169(3), 231-244. https://doi. org/10.1016/j.desal.2004.03.013.

Zaw, M., \& Emett, M. T. (2002). Arsenic removal from water using advanced oxidation processes. Toxicology Letters, 133(1), 113118. https://doi.org/10.1016/S0378-4274(02)00081-4. 